\title{
Measuring Physiological Changes during the Transition to Life after Birth
}

\author{
Jeroen J. van Vonderen ${ }^{a}$ Arno A.W. Roest ${ }^{b}$ Melissa L. Siew ${ }^{c}$ Frans J. Walther $^{a}$ \\ Stuart B. Hooper ${ }^{\mathrm{C}}$ Arjan B. te Pas ${ }^{\mathrm{a}}$ \\ Divisions of a Neonatology and ${ }^{b}$ Pediatric Cardiology, Department of Pediatrics, Leiden University Medical Center, \\ Leiden, The Netherlands; ' Ritchie Center, Monash Institute of Medical Research, Monash University, \\ Melbourne, Vic., Australia
}

\section{Key Words}

Neonatal transition $\cdot$ Newborn $\cdot$ Resuscitation

\begin{abstract}
The transition to life after birth is characterized by major physiological changes in respiratory and hemodynamic function, which are predominantly initiated by breathing at birth and clamping of the umbilical cord. Lung aeration leads to the establishment of functional residual capacity, allowing pulmonary gas exchange to commence. This triggers a significant decrease in pulmonary vascular resistance, consequently increasing pulmonary blood flow and cardiac venous return. Clamping the umbilical cord also contributes to these hemodynamic changes by altering the cardiac preload and increasing peripheral systemic vascular resistance. The resulting changes in systemic and pulmonary circulation influence blood flow through both the oval foramen and ductus arteriosus. This eventually leads to closure of these structures and the separation of the pulmonary and systemic circulations. Most of our knowledge on human neonatal transition is based on human (fetal) data from the 1970s and extrapolation from animal studies. However, there is renewed interest in performing measurements directly at birth. By using less cumbersome techniques (and probably
\end{abstract}

more accurate), our previous understanding of the physiological transition at birth is challenged, as well as the causes and consequences for when this transition fails to progress. This review will provide an overview of physiological measurements of the respiratory and hemodynamic transition at birth. Also, it will give a perspective on some of the upcoming technological advances in physiological measurements of neonatal transition in infants who are unable to make the transition without support.

(c) 2014 S. Karger AG, Basel

\section{Introduction}

The fetal to neonatal transition at birth starts when the newborn takes the first breaths, initiating major physiological respiratory and hemodynamic changes [1]. During the initial breaths lung liquid is cleared and air remains in the lung at the end of expiration, providing a functional residual capacity (FRC) [2]. Aeration of the lungs decreases pulmonary vascular resistance (PVR) and systemic vascular resistance (SVR) is increased by clamping of the umbilical cord after birth [3]. These events trigger major changes in the newborn's circulatory system [3]. Uniform lung aeration, establishing FRC 


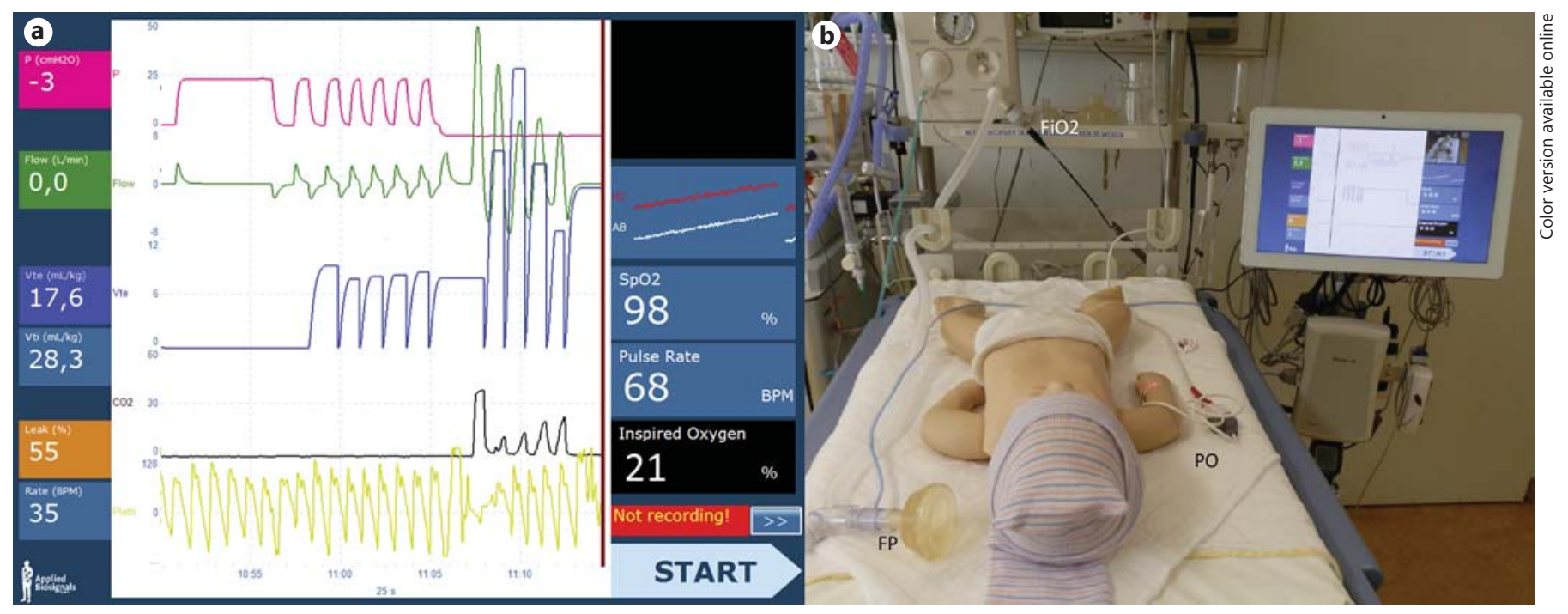

Fig. 1. a Respiratory tracing showing pressure (red), flow (green), expiratory volume (blue), capnography (black) and HR plethysmography (yellow) in waveforms. It also provides $\mathrm{HR}, \mathrm{SO}_{2}, \mathrm{FiO}_{2}$, inspiratory volume, expiratory volume and leak in numerals. b Respiratory function monitor (Applied Biosignals, Weener, Ger- many) and set-up as currently used for physiological research of the newborn infant. The flow probe (FP) is connected to the face mask. Also, an oxygen analyzer $\left(\mathrm{FiO}_{2}\right)$ and pulse oximeter $(\mathrm{PO}) \mathrm{can}$ be added to monitor supplied oxygen as well as $\mathrm{SO}_{2}$ and $\mathrm{HR}$. and decreasing PVR are required to commence effective pulmonary gas exchange, which in turn improves the infant's heart rate (HR), cardiac output (CO) and oxygenation.

Although many observations have been made in humans [2], most of the understanding of the fetal to neonatal transition originates from animal studies [4]. Investigating this major life event in the delivery room is difficult as the neonatal transition can be very rapid and as a result time pressure is high. In addition, most of the techniques used for physiological measurements performed in the 1960-1980s would currently be considered unethical (X-rays, esophageal balloons, reverse plethysmography, umbilical catheterization, and angiocardiography) $[1,5]$. However, less cumbersome and noninvasive techniques are currently used to gather observational data in the delivery room $[6,7]$, challenging our understanding of transition and resuscitative practices (fig. 1). In addition, more sophisticated techniques and approaches are now used in animal models to investigate the transition.

In this review, we will give an overview of the information obtained from current experimental and human physiological studies, which are designed to better understand the pulmonary and hemodynamic transition at birth [8]. Equipped with this new information we will also offer some future insights on how neonatal transition could be facilitated in infants who are unable to make this transition without support.

\section{Pulmonary Transition}

\section{Breathing at Birth}

Fetal breathing movements (FBM), needed for lung growth and development, are very similar to breathing activity after birth. Fetal respiratory drive is controlled by similar stimuli (hypoxia and hypercapnia), which arises from the respiratory center and mainly causes activation of the diaphragm via the phrenic nerve [6]. However, as FBM are restricted to levels of fetal activity, they are discontinuous, occurring $<50 \%$ of the time. Further, although most FBM generate transpulmonary pressures of $<20 \mathrm{~cm} \mathrm{H}_{2} \mathrm{O}$, fetuses commonly can make large inspiratory efforts $\left(>30 \mathrm{~cm} \mathrm{H}_{2} \mathrm{O}\right)[9,10]$, demonstrating that they are capable of generating transpulmonary pressures needed to aerate the lungs after birth [7]. The mechanisms controlling the switch to continuous breathing after birth are currently unknown. There is a general belief that activation of chemoreceptors (particularly an increase in arterial $\mathrm{CO}_{2}, \mathrm{PaCO}_{2}$ ) and physical stimuli (light, temperature and handling) trigger the onset of large in- 
spiratory efforts. Data on this matter are scarce, although animal studies have shown that cooling lambs at birth elicits normal quiet breathing, but no large initial gasps [8]. In contrast, painful stimuli elicit gasps in unanesthetized lambs with an intact umbilical cord, but not sustained respiratory movements [9].

Although hypoxia is considered to be a stimulus for respiratory drive, it remains questionable if this also accounts for the increased respiratory drive at birth $[10,11]$. Hypoxia is known to inhibit breathing movements in the fetus and the hypoxic sensitivity is relatively low shortly after birth [10]. After birth, hypoxia increasingly stimulates respiratory drive in the newborn due a temporal change in $\mathrm{O}_{2}$ sensitivity, which increases days/weeks after birth [10]. Although most preterm infants breathe at birth $[12,13]$, it is not known when the switch from respiratory suppression to a stimulation occurs in response to hypoxia. It is possible that hypoxia immediately after birth will produce a weakened or even absent respiratory drive, particularly in preterm infants. Indeed, maturation of the hypoxic sensitivity increase is delayed in preterm lambs [10]. In contrast, hyperoxia has been shown to delay the onset of breathing in asphyxiated rats, but it is difficult to extrapolate this finding as the rats were more than a week old [14]. Also, a delay of the first breath was observed in asphyxiated term infants at birth when 100\% oxygen with no titration was given during resuscitation [15]. However, the first breath was observed and not measured and it is very difficult to identify the first breath, especially when the infant is ventilated [16].

As shown in animals, resuscitation with $100 \%$ oxygen compared to room air could also delay the onset of breathing via a mechanism that may involve both hyperoxemic and hypocapnic inhibition of chemoreceptors [14], although these animals were more than a week old at the time of the study. Antenatally, FBM are inhibited by hypoxia, but hypoxic sensitivity is relatively low shortly after birth and gradually increases days/weeks after birth [10]. Hypercapnia is a powerful stimulant for respiratory drive both before and after birth and could induce the large respiratory efforts observed. However, not all infants will be hypercapnic immediately after birth.

\section{Lung Liquid Clearance and Aeration}

Experimental studies have predicted that the stress of labor starts fetal lung liquid clearance due to the release of adrenaline, which stimulates pulmonary epithelial cells to activate luminal surface sodium channels. This reverses both the $\mathrm{Na}^{+}$flux and the osmotic gradient across the epithelium, causing reabsorption of lung liq- uid [17]. However, the dominant role of sodium channel activation for lung liquid reabsorption after birth has been challenged by recent studies [18]. These studies used phase-contrast X-ray imaging to image air entry into the lungs during the first breaths in newborn rabbits. They demonstrated that liquid clearance exactly coincides with inspiration and occurs very rapidly $(3 \mathrm{ml} / \mathrm{kg}$ over the first 5 breaths, at $35 \mathrm{l} / \mathrm{kg} / \mathrm{h}$ ). They concluded that airway liquid clearance cannot solely be explained by activation of sodium channels, and probably involves transpulmonary pressures generated by the inspiratory effort [18]. Cell membrane water channels (aquaporins, AQPs) could play an essential role in this process. During pregnancy different types of AQPs are expressed [19] and at birth the expression of pulmonary AQPs changes. Through these channels water can be absorbed into the interstitium in the first days after birth [20,21]. In preterm infants the expression of AQPs differs compared to term infants, possibly increasing the incidence of neonatal respiratory distress syndrome and bronchopulmonary dysplasia [20].

Lung liquid clearance by 'vaginal squeeze' is an old theory some authors still consider as an important mechanism [22]. This theory originates from studies [5, 23] performed in 1917 and repeated in 1962 using X-ray imaging showing compression of the fetal chest of term infants passing through the birth canal. In later studies intrathoracic pressures of $70 \mathrm{~cm} \mathrm{H}_{2} \mathrm{O}$ were measured and oral expulsion of lung liquid was observed during delivery [24-26].

However, the little resistance that the chest offers when following the head in the birth canal makes it unlikely that 'vaginal squeeze' per se significantly influences liquid clearance [27, 28]. In contrast, as postural changes during labor can cause lung liquid loss [29], flexion of the fetal trunk, which increases abdominal pressure and elevates the diaphragm, are more likely to cause liquid expulsion $[22,23]$.

Another theory, observed in 1891 in excised lungs, suggested the increase in pulmonary circulation would be responsible for lung aeration ('capillary erection') [3032]. However, this theory has been abandoned since experimental studies $[33,34]$ have shown that pulmonary vasodilation occurs in response to lung aeration, leading to a gradual reduction in pulmonary arterial pressure.

Thoracic recoil after passage through the birth canal is also described to explain lung aeration, as suggested in 1901 [35]. In 1962 Karlberg et al. [1, 36] used reverse plethysmography for lung volume measurements in human infants and reported that elastic recoil of the chest 
after expulsion from the birth canal caused air entering the lung $[1,23,36]$. The measurements were repeated later, but elastic recoil forcing air into the lung could not be confirmed [25].

Karlberg et al. [36] and Saunders and Milner [25] have also measured transesophageal pressures using an esophageal balloon catheter. Karlberg et al. [36] observed that relatively large subatmospheric pressures $(20-40 \mathrm{~cm}$ $\mathrm{H}_{2} \mathrm{O}$ ) were necessary before air started entering the lung, which was considered to be the 'opening pressure' needed to overcome resistance and newly formed surface tension [37]. However, Saunders and Milner [25] could not confirm this and stated that the balloon in Karlberg's study was probably misplaced. Although 'opening pressure' is a misnomer, as the lungs are not collapsed at birth, it is still used as rationale for initially providing higher ventilation pressures during neonatal resuscitation [32].

More recently, phase-contrast X-ray imaging in a newborn rabbit model demonstrated that lung liquid clearance almost exclusively occurs ( $>95 \%)$ during inspiration [4]. The transpulmonary pressure gradients generated during inspiration are likely to be primarily responsible for the rapid clearance of airway liquid immediately after birth [4]. That is, the inspiratory effort reduces (becomes more subatmospheric) in both the intrapleural space and the interstitial tissue surrounding alveoli, which forces liquid to move across the alveoli's epithelium into the interstitium. This causes liquid to accumulate in the interstitial space, forming perivascular fluid cuffs [38], resulting in an increase in resting interstitial tissue pressure $[4,39,40]$. End expiratory pressures generated during braking of the expiration (breath holds, crying), surfactant and probably activated epithelial sodium channels are likely to be important in preventing liquid moving back into the alveoli [41]. The sum of lung liquid moving into the interstitium and being replaced by air that occupies the airways explains the increase in thorax circumference and shape before and after lung aeration was made visible in radiographs from both humans [42] and newborn rabbits [43]. This has been indirectly confirmed by Miserocchi and Agostoni [44] who found a larger pressure in the interstitium at the end of inspiration, showing that both FRC and pleural liquid pressure increased simultaneously. The movement of liquid from the airways into the surrounding lung tissue has also been visualized in ventilated preterm rabbit pups [4]. Eventually, liquid in the interstitium is cleared in approximately $6 \mathrm{~h}$ via the blood and lymph vessels $[4,39$, 40].

\section{Creating and Maintaining FRC}

From the start of research in respiration during neonatal transition several theories have been suggested describing FRC creation and maintenance right after birth, which are necessary for adequate gas exchange. One theory described that alveoli were splinted open by 'air trapping', i.e. more air is inspired than exhaled [45]. 'Airtrapping' could occur due to braking of expiration, which was described previously as 'frog breathing' [46-48]. Karlberg and Koch [47], using chest X-rays and reverse plethysmography, described the first breath as a deeper and slower breath than subsequent breaths, composed of a large inspiration followed by a braked, slow expiration. As a result, large changes in esophageal pressures were found to be related to both changes in inspiratory volume and the subsequent braking of expiration [17, 41]. During expiratory braking the infant builds up a large intrathoracic pressure by simultaneously closing the glottis and contracting the abdominal muscles. The physiological consequences of this are unclear, although an increase in airway liquid clearance is unlikely because pressure within the interstitial tissue will also increase simultaneously, resulting in little or no change in transpulmonary pressure [40].

Several breathing patterns have recently been described in infants at birth using a hot-wire anemometer attached to a mask $[41,48]$. Patterns that slow expiration (expiratory hold, slow expiration, crying and grunting) and shorten expiratory time (panting) were thought to be important for maintaining FRC in the newborn period [41]. Preterm infants were more commonly found to use breath-holds and cause a complete cessation of expiratory flow, whereas term infants most commonly slowed expiration during crying [48]. Imaging experiments in spontaneously breathing newborn rabbits have confirmed the role of expiratory braking in preventing liquid moving back into the airways and maintaining FRC [18].

Using reversed plethysmography, Karlberg and Koch [47] found that in the first minutes after birth an infant's FRC can reach levels of 20-40 ml. Mortola et al. [49], using a face mask with a pneumotachograph attached, measured an average FRC of $42 \pm 26 \mathrm{ml}$ in term infants. However, mask leak could have been a confounding factor. Recent animal studies confirmed that large amounts of FRC are established during the first breaths $(3 \mathrm{ml} / \mathrm{kg}$ over the first 5 breaths) [18]. However, the speed at which FRC is established and maintained is variable $[7,18]$. This is due to the variable effect of the inspiratory efforts, the reentry of liquid into the airways and the mechanisms such as expiratory holds [18].

Neonatology 2014;105:230-242

DOI: $10.1159 / 000356704$ 
Surfactant also plays an important role in creating and maintaining FRC at birth, by reducing the surface tension, lung recoil and the transpulmonary pressure gradient for lung liquid moving back to the alveolar space [50, 51]. In addition, surfactant greatly increases the uniformity of lung aeration, which indicates that surface tension determines whether the air/liquid interface progresses down both airways at each airway branch [51].

\section{Hemodynamic Transition}

As with the respiratory system, the cardiovascular system undergoes a major transformation after birth. The major components of these transformations occur within minutes of commencing pulmonary ventilation (fig. 2, 3) However, the cardiovascular transition requires hours to days to complete. The immediate consequence of the neonatal transition is the direct reversal of vascular shunts of the foramen ovale (FO) and ductus arteriosus (DA). Due to the continued patency of the FO and DA, transition is prolonged. After birth the increasing afterload will increase the likelihood of left-to-right shunt through the DA in the first days after birth. However, DA constriction will cause shunting through the DA to decrease [52]. Changes in SVR and the decrease in PVR resistance that occur during transition will cause blood pressure (BP) and flows in the pulmonary and systemic circulations to change. This promotes functional closure of the FO, thus completing transition. The ductus venosus (DV) will remain patent up to days after birth [53]. However, it will not be of further influence to the cardiovascular system.

In fetal sheep, depending upon the gestational age, approximately $30-50 \%$ of combined CO (right and left ventricle) flows to the placenta [54] and therefore $30-50 \%$ of cardiac venous return must come from the placenta. Approximately $50 \%$ of umbilical venous blood flow in sheep fetuses [55] and 30\% of blood flow in the human fetuses [56] passes through the DV, bypassing the liver. A large proportion of this oxygenated placental blood passes through the FO and enters the left atrium [57]. The remainder of the venous return, which mostly consists of poorly oxygenated blood from the superior and inferior vena cava, enters the right atrium and is directed into the right ventricle. However, as PVR is high in the fetus, most of the right ventricular output (RVO, 90\%) bypasses the lungs and is shunted through the DA into the aorta [54, 58]. A large portion of this deoxygenated blood will flow back to the placenta as this organ's vascular resistance is lower than the vascular resistance of the fetus' lower body [34].
The Effect of Breathing on Hemodynamic Transition

The decrease in PVR, which is necessary for adequate pulmonary gas exchange after birth, is triggered by the onset of pulmonary ventilation. This emphasizes that establishing adequate breathing at birth is important for a proper hemodynamic transition as this has significant influence on the pulmonary blood flow $[3,34,54,59]$. Lind and Wegelius [60] visualized the large blood flow through the pulmonary artery in term infants using angiocardiography with Umbradil injected in the umbilical vein directly after birth. Up to $50 \%$ of the increase in pulmonary blood flow was supplied by a left-to-right shunt through the DA [54], caused by the differential pressures between pulmonary and systemic circulation. As a consequence, particularly the timing in the reversal of blood flow shunting through the DA (from right-to-left to leftto-right) is unclear. The change in shunting direction will create disturbance of the blood flow. This is likely to promote and contribute to anatomical closure of the vascular shunts (DA and FO) separating pulmonary and systemic circulations $[54,58]$.

\section{Effect of Umbilical Cord Clamping on Hemodynamic} Transition

Clamping the umbilical cord at birth has a large impact on the fetal circulation and plays an integral role in the transition. The acute loss of the high-flow and low-resistance placental vascular bed has two implications: (1) SVR instantly increases and (2) venous return to the heart is decreased by $30-50 \%$ [54]. Both have the potential to compromise the infant's CO.

The timing of cord clamping in relation to lung aeration could influence transition extensively. While before birth the left ventricular preload is mostly dependent on umbilical venous blood flow, after cord clamping the left ventricular output (LVO) becomes largely dependent on pulmonary blood flow and pulmonary venous return. A recent study in preterm lambs hypothesized that breathing before cord clamping would improve cardiovascular stability. It was shown that cord clamping before ventilation reduced HR by $40 \%$, and decreased RVO and blood flow in the carotid artery. It was observed that carotid blood flow remained stable and the decrease in HR and RVO associated with cord clamping were greatly reduced when ventilation was commenced before cord clamping [61]. It is likely that this cardiovascular stability plays an important part in the benefits of delayed cord clamping such as improved tissue perfusion, lower incidence of necrotizing enterocolitis and intraventricular hemorrhage [62]. 
Fig. 2. Schematic drawing of the fetal circulation. Red indicates blood with a high $\mathrm{SO}_{2}$ and blue indicates blood with a low $\mathrm{SO}_{2}$. Before birth blood from the placenta enters the infant through the DV and passes into the right atrium. $2 / 3$ of the blood shunts through the open $\mathrm{FO}$ and $1 / 3$ passes through to the right ventricle and into the pulmonary artery (PA). 90\% of the blood shunts through the DA and only $10 \%$ enters the lungs due to the high PVR.
Fig. 3. Schematic drawing of the neonatal circulation just after birth. Red indicates blood with a high $\mathrm{SO}_{2}$ and blue indicates blood with a low $\mathrm{SO}_{2}$. After birth the umbilicus is clamped and there is loss of $30-50 \%$ of total venous return. Pulmonary resistance decreases due to aeration of the lungs causing increased pulmonary blood flow through the pulmonary artery (PA). Blood flow through the DA and FO becomes bidirectional. Up to $50 \%$ of the pulmonary blood flow arises from the DA through via a left-to-right shunt.
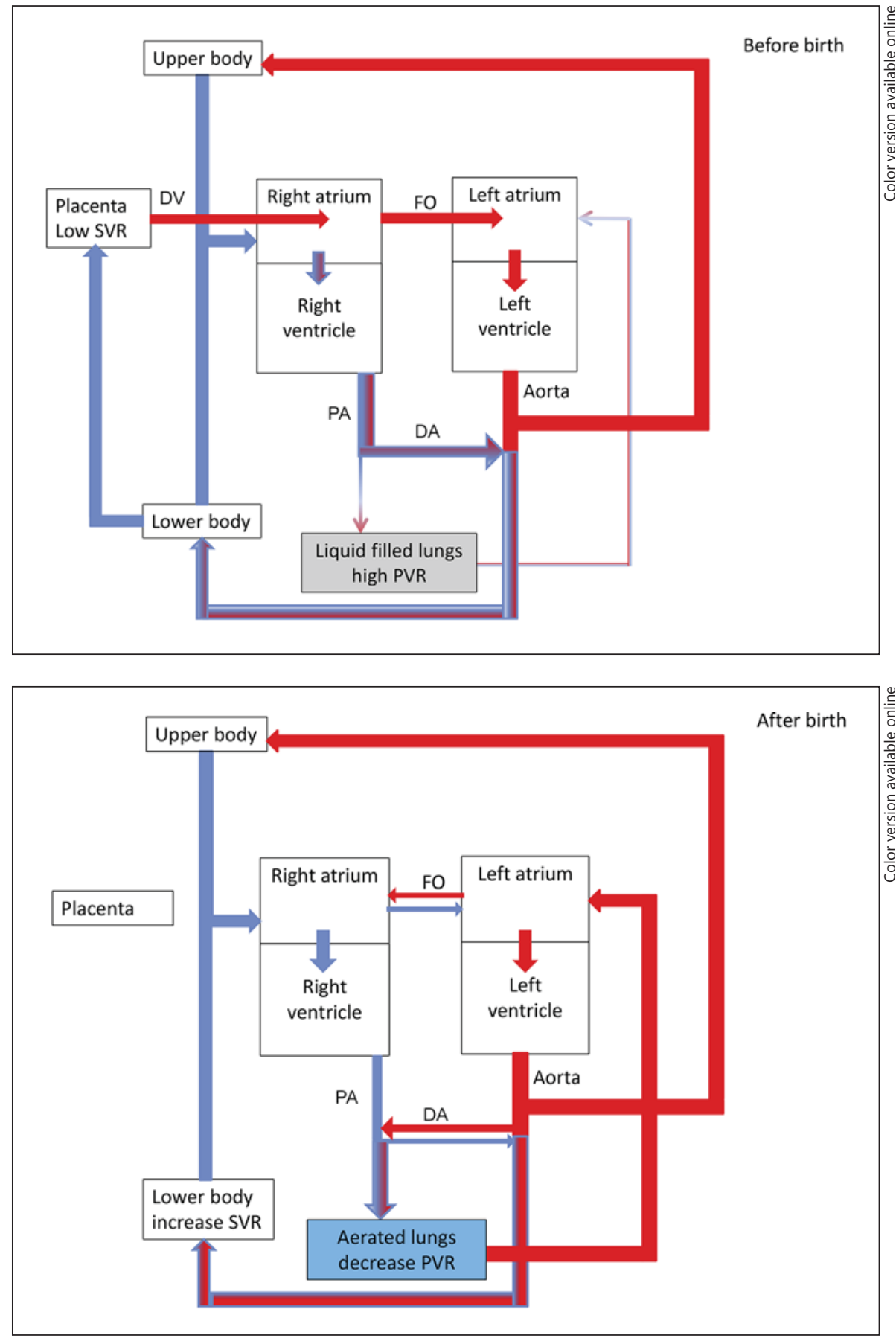

There are little physiological human data available measuring the quantity and characteristics of fetoplacental transfusion between birth and cord clamping [63-65]. Mechanisms have been suggested that could influence fetoplacental transfusion (e.g. uterine contractions and breathing), but these still need to be investigated $[61,66]$.

Physiological Measurements during Neonatal Transition

\section{Measurements for Evaluating Transition}

\section{Heart Rate}

Currently the only parameter used clinically to evaluate the hemodynamic transition is $\mathrm{HR}$, which is believed to be the primary measure of adequate transition [67]. A cut-off value of HR of 100 beats per minute was suggested

Neonatology 2014;105:230-242 
by Virginia Apgar to characterize adequate transition. Nonetheless, a HR of $<100$ beats per minute is commonly observed in healthy term infants in the first minutes after birth, followed by a fast and significant increase [68]. The relatively low HR in the first minutes after birth is assumed to be caused by a hypoxia-stimulated bradycardia that involves a parasympathetic-activated vagal reflex [69]. However, the transient bradycardia after birth could also be caused by immediate umbilical cord clamping before the lungs are aerated, which decreases both LVO and RVO [61]. Early cord clamping causes the SVR to increase before PVR is reduced and pulmonary blood flow can increase. As a consequence of the low pulmonary vascular return, together with the sudden decrease in rightto-left shunting through the FO, left ventricular preload is low and therefore a baroreflex-provoked bradycardia could arise [61].

\section{Oxygen Saturation}

Several experimental and human studies [70-73] show that fetal oxygen saturation $\left(\mathrm{SO}_{2}\right)$ is low $(45-65 \%)$ and can be even lower during labor. However, directly after birth it was found that there is no significant difference in oxygen uptake between term infants born by cesarean section or infants born vaginally $(6.58 \mathrm{ml} / \mathrm{min} / \mathrm{kg})[74] . \mathrm{SO}_{2}$ measured peripherally is, however, not necessarily related to central oxygen uptake. Until recently pink color was seen as a sign of a proper transition. It was found that there is a large variation in $\mathrm{SO}_{2}$ when clinicians stated an infant to be pink [75]. $\mathrm{SO}_{2}$ should preferably be measured preductally using pulse oximetry [76]. In 2010 a lower and slowly rising $\mathrm{SO}_{2}$ was considered acceptable during the transitory phase according to the normograms presented by Dawson et al. [77]. Infants delivered by cesarean section have a significantly lower $\mathrm{SO}_{2}$ and require a longer time period to reach $\mathrm{SO}_{2} \geq 85 \%$ [77-79]. This could lead to a delayed or compromised transition. Also, infants born with a gestational age $<37$ weeks without medical intervention required a longer time to reach $\mathrm{SO}_{2}$ ( 87 vs. $90 \%$ at 5 min after birth) [77].

\section{CO and Stroke Volume}

$\mathrm{CO}$ is determined by both HR and stroke volume (SV; $\mathrm{CO}=\mathrm{HR} \cdot \mathrm{SV})$. It is sometimes still assumed that SV cannot be altered in the neonate because the contractility of the myocardium characteristically functions high on the Frank-Starling curve and is unable to increase further, as well as the fetal myocardium [80]. This would imply that a change in end diastolic volume cannot be accompanied by a large change in $\mathrm{CO}$. However, it has been shown in sheep fetuses that SV can be adapted [81]. Echocardiography has been used to monitor CO during the neonatal transition [82-84]. However, this data was collected in the hours to days after birth when the major changes of neonatal transition already occurred. Recently, Noori et al. [85] were the first to use echocardiography shortly after birth and observed that as a consequence of rising SV, LVO non-significantly increased from $168 \pm 42 \mathrm{ml} / \mathrm{kg} /$ $\mathrm{min}$ at $3-7 \mathrm{~min}$ to $186 \pm 26 \mathrm{ml} / \mathrm{kg} / \mathrm{min}$ at $9-14 \mathrm{~min}$ after birth. HR decreased and SV increased between the two measurement periods. It is possible that the increase in LVO was missed in the first minutes as the first measurements were conducted between 3 and $7 \mathrm{~min}$. However, Noori et al. [85] have shown that increasing SV is important for CO during the first minutes after birth as it is later during transition [52].

\section{Blood Pressure}

BP is determined by SVR and CO and although it is not well correlated to systemic blood flow, it is considered an important value for hemodynamic monitoring of critically ill infants [86]. However, while HR is considered important for decision making in the delivery room, BP is rarely used for evaluating the neonatal transition or the need for resuscitation at birth.

There is very little data of $\mathrm{BP}$ at birth and reference values are lacking. Although the exact time points of measurements are unknown, in 1938 Woodbury et al. [87] inserted an umbilical arterial line in term infants directly after birth and observed a mean systolic artery pressure of $80.1 \pm 8.1 \mathrm{~mm} \mathrm{Hg}$ and diastolic pressure of $46.3 \pm 8.2$ $\mathrm{mm} \mathrm{Hg}$. BP was markedly influenced by crying, administration of fluids [87] and increasing gestational age [88]. Interestingly, small undulations in the $\mathrm{BP}$ concomitant with breathing were seen [87]. Ashworth and Neligan [89] (using a sphygmomanometer on the right arm, preductally) observed lower systolic BPs $( \pm 10 \mathrm{~mm} \mathrm{Hg}$ difference) in the hours following birth when the cord was clamped during delivery, compared to when the cord was clamped after birth. This could infer that when the cord is clamped before pulmonary blood flow has increased there will be less circulating volume. In a more recent study in term infants a mean BP of $42 \pm 11 \mathrm{~mm} \mathrm{Hg}$ at 5 min after birth was measured [90]. It could be helpful to measure $\mathrm{BP}$ preductally during transition to evaluate the hemodynamic transition and assess the $\mathrm{CO}$.

\section{Gas Exchange Measurements}

Palme-Kilander and Tunell [91] and Tunell et al. [92] measured carbon dioxide production $\left(\mathrm{VCO}_{2}\right)$, using a face 
Table 1. Respiratory parameters for different breathing patterns for infants who did not require respiratory support with a gestational age of $29 \pm 1.9$ weeks and mean birth weight of $1,220 \pm 412 \mathrm{~g}[41,48]$

\begin{tabular}{|c|c|c|c|c|}
\hline & $\begin{array}{l}\text { VTE, } \\
\mathrm{ml} / \mathrm{kg}\end{array}$ & $\begin{array}{l}\text { Respiratory } \\
\text { rate, } \min ^{-1}\end{array}$ & $\begin{array}{l}\text { Inspiratory } \\
\text { time, s }\end{array}$ & $\begin{array}{l}\text { Expiratory } \\
\text { time, } s\end{array}$ \\
\hline \multicolumn{5}{|c|}{ Preterm infants ( $<32$ weeks; CPAP) } \\
\hline Braked expiration & $7.2 \pm 3.8$ & $60 \pm 30$ & $0.32 \pm 0.14$ & $1.03 \pm 0.84$ \\
\hline Unbraked expiration & $3.7 \pm 2.2$ & $90 \pm 26$ & $0.30 \pm 0.09$ & $0.41 \pm 0.16$ \\
\hline \multicolumn{5}{|l|}{ Term infants } \\
\hline Braked expiration & $6.8 \pm 4.2$ & $50 \pm 23$ & $0.33 \pm 0.16$ & $1.33 \pm 1.02$ \\
\hline Unbraked expiration & $5.5 \pm 3.4$ & $91 \pm 31$ & $0.30 \pm 0.13$ & $0.43 \pm 0.26$ \\
\hline \multicolumn{5}{|l|}{ All infants } \\
\hline Expiratory hold & $5.8 \pm 4.1$ & $32 \pm 11$ & $0.36 \pm 0.10$ & $1.85 \pm 1.14$ \\
\hline Slow expiration & $3.5 \pm 2.3$ & $48 \pm 16$ & $0.34 \pm 0.15$ & $1.10 \pm 0.90$ \\
\hline Crying/grunting & $7.5 \pm 4.2$ & $42 \pm 18$ & $0.38 \pm 0.14$ & $1.30 \pm 0.75$ \\
\hline Normal expiration/ & $42+15$ & $54+4$ & $040+0.08$ & $0.65+0.11$ \\
\hline Panting & $3.1 \pm 1.7$ & $88 \pm 18$ & $0.34 \pm 0.07$ & $0.41 \pm 0.14$ \\
\hline
\end{tabular}

mask and collection system, directly after birth in both breathing and ventilated infants. Asphyxiated preterm and term infants needing assisted ventilation at birth had similar $\mathrm{VCO}_{2}$ in the first minutes after birth $[91,92]$. However, breathing infants had higher $\mathrm{VCO}_{2}$ values than ventilated infants (5-7 vs. $2-4 \mathrm{ml} / \mathrm{kg} / \mathrm{min}$ ), which probably reflects a lower temporal increase in FRC in ventilated infants, indicating that ventilation was not as effective as breathing $[74,93]$. However, a higher energy cost associated with spontaneous breathing cannot be discounted [94].

A similar phenomenon was observed in a recent trial testing the use of end-tidal carbon dioxide levels $\left(\mathrm{ETCO}_{2}\right)$ to keep $\mathrm{PaCO}_{2}$ levels within range [95]. Although the number of out-of-range $\mathrm{PaCO}_{2}$ values was not reduced, $\mathrm{ETCO}_{2}$ was lower during ventilation than during breathing [95]. While studies in the neonatal intensive care unit have found that $\mathrm{ETCO}_{2}$ closely correlates with $\mathrm{PaCO}_{2}[96-$ 98], it is important not to extrapolate these findings to the situation in the delivery room, when the lung is partially liquid filled. The assumption that $\mathrm{ETCO}_{2}$ will approximate $\mathrm{PaCO}_{2}$ levels relies on the fact that $\mathrm{CO}_{2}$ exchange in the lung is not diffusion limited. However, a recent study demonstrated that during the early transition period, $\mathrm{ETCO}_{2}$ values are primarily determined by inspiratory lung volumes [99].

\section{Tidal Volume}

Although extrapolated from studies performed later in life, during ventilation at birth, tidal volumes between 4 and $8 \mathrm{ml} / \mathrm{kg}$ are considered adequate. However, at birth, term infants use significantly larger tidal volumes for their first breaths $(11 \pm 5 \mathrm{ml} / \mathrm{kg})[1,49]$. Similarly, Milner and Saunders [100] measured a mean tidal volume of 44.6 $\mathrm{ml}$ (range 13.4-90 $\mathrm{ml}$ ) for the first breath. te Pas et al. [48], who measured tidal volumes in preterm infants breathing on CPAP at birth and during different breathing patterns, found a range of volumes between $3.1 \pm 1.7 \mathrm{ml} / \mathrm{kg}$ and 7.5 $\pm 4.2 \mathrm{ml} / \mathrm{kg}$ (table 1). In infants without support at birth, tidal volumes of more mature preterm infants were comparable to term infants $(6.7 \pm 3.9$ vs. $6.5 \pm 4.1 \mathrm{ml} / \mathrm{kg}$; NS $)$ [41].

\section{Tissue Perfusion}

For determination of the tissue perfusion two methods can be used: the perfusion index (PI) and near infrared spectroscopy (NIRS). PI is the ratio of pulsatile blood flow/nonpulsatile static blood flow and is deducted from the strength of the photo-plethysmographic signal emitted during pulse oximetry [101]. At birth, a consistent PI was observed in healthy term infants and values were higher when compared to infants with sepsis (PI at $1 \mathrm{~min}$ $4.50 \pm 0.83$ vs. $1.74 \pm 0.32$ and at $5 \mathrm{~min} 4.42 \pm 2.10$ vs. 2.18 \pm 1.02 ) [102]. However, since various factors can influence PI, e.g. changing temperature and local skin vasoconstriction, its value for evaluating transition remains questionable.

NIRS is a technique developed for monitoring perfusion of brain tissue. In term infants at birth regional $\mathrm{SO}_{2}$ of the brain ( $\mathrm{rSO}_{2}$ brain) rapidly adapts to extrauterine life with $44 \%$ at $3 \mathrm{~min}$ to $76 \%$ at $7 \mathrm{~min}$, after which it remained stable [90]. $\mathrm{rSO}_{2}$ brain was not affected by manner of birth, 
Table 2. Tidal volumes and pressures in infants just after birth during resuscitation measured using a respiratory function monitor

\begin{tabular}{|c|c|c|c|c|c|}
\hline & $\begin{array}{l}\text { VTE of sponta- } \\
\text { neous breaths, } \\
\mathrm{ml} / \mathrm{kg}\end{array}$ & $\begin{array}{l}\text { VTE of pro- } \\
\text { longed inflation, } \\
\mathrm{ml} / \mathrm{kg}\end{array}$ & $\begin{array}{l}\text { VTE of infla- } \\
\text { tions (PPV), } \\
\mathrm{ml} / \mathrm{kg}\end{array}$ & $\begin{array}{l}\text { Breaths between } \\
\text { inflations } \\
(\mathrm{CPAP}), \mathrm{ml} / \mathrm{kg}\end{array}$ & $\begin{array}{l}\text { Breaths coincid- } \\
\text { ing with infla- } \\
\text { tions, } \mathrm{ml} / \mathrm{kg}\end{array}$ \\
\hline \multicolumn{6}{|l|}{ Preterm infants (<32 weeks) } \\
\hline Schilleman et al. [16], 2012 & & $0.8(0-5.6)$ & $3.7(1.4-6.7)$ & $3.3(2.1-6.6)$ & $4.6(2.1-7.8)$ \\
\hline Schmölzer et al. [108], 2010 & & & $8.0(5.2-11.2)$ & & \\
\hline $\begin{array}{l}\text { Term infants } \\
\text { Milner et al. [100], } 1977 \\
\text { (face mask) }\end{array}$ & & & $4.1(1.7-6.4)$ & & \\
\hline $\begin{array}{l}\text { Milner et al. [100], } 1977 \\
\text { (intubated) }\end{array}$ & & & $7.8(0.4-11.7)$ & & \\
\hline Mortola et al. [49], 1982 & $11.7 \pm 5.5$ & & & & \\
\hline Karlberg et al. [1], 1962 & $10.6 \pm 4.4$ & & & & \\
\hline $\begin{array}{l}\text { Hull et al. [112], } 1969 \\
\text { (asphyxiated intubated) }\end{array}$ & & & & & $10.8 \pm 1.4$ \\
\hline
\end{tabular}

indicating that blood flow to the brain is possibly determined by auto regulation independently from the mode of delivery [103]. Also, fractional oxygen extraction $\left[\left(\mathrm{SO}_{2}-\mathrm{rSO}_{2}\right.\right.$ brain $\left.) / \mathrm{SO}_{2}\right]$ can be determined using NIRS, which is a measure for the amount of oxygen consumed by the tissue. In the first $5 \mathrm{~min}$ after birth fractional oxygen extraction rises significantly and thereafter it levels [90]. When assuming that cerebral metabolism remains stable, fractional oxygen extraction could also be used as an indirect parameter for cerebral blood flow.

\section{Physiological Measurements during Resuscitation}

Until recently, accurate physiological recordings were not used to evaluate neonatal resuscitation, but instead subjective and inaccurate clinical observations were used $[67,75,104-107]$. Several recent studies have now addressed the importance of monitoring neonatal resuscitation by measuring $\mathrm{HR}, \mathrm{SO}_{2}$ and respiratory function in the immediate newborn period [16, 108-110].

Observations in the early 70s by Milner et al. [111] showed that ventilation during neonatal resuscitation of asphyxiated term infants was often inadequate, only small tidal volumes were administered and substantial FRC was only created when spontaneous breathing started. Recent- ly, Schilleman et al. [16] also observed much lower tidal volumes during mask ventilation of preterm infants at birth compared to the volumes inhaled during spontaneous breathing (table 2). Spontaneous breathing occurred more often in between and during inflations than clinicians were aware, which might have contributed to the effect of resuscitation [16]. Schmölzer et al. [108] measured higher tidal volumes during ventilation, probably as a result of spontaneous breaths in between and during inflations, as these were not separately identified and could have been mistaken for inflations during analysis.

Asphyxiated infants often do not breathe at birth. Nevertheless, in intubated asphyxiated infants, tidal volumes of $10.8(1.4) \mathrm{ml} / \mathrm{kg}$ were measured during resuscitation shortly after birth [112]. The pressure signals [112] show a pressure drop during inflation. This might implicate a spontaneous inspiration which could explain the high tidal volumes measured.

The observed breaths in asphyxiated infants could be caused by a reflex induced by ventilation [113]. Certain reflexes such as the Head's paradoxical reflex could be triggered by alveolar distention during positive pressure ventilation causing spontaneous breaths [114]. Furthermore, the reflex was found to be very important for the formation of FRC, resulting in volumes of up to $10 \mathrm{ml}$ and negative endotracheal pressures of up to $30 \mathrm{~cm} \mathrm{H}_{2} \mathrm{O}$ in 
asphyxiated infants [115]. Other reflexes have also been observed, triggering spontaneous expiration after the first manual inflation in newborn infants [112]. This could possibly be caused by the Hering-Breuer reflex [116], acting as a mechanism to prevent overdistension of the airways.

\section{Conclusion and Future Perspectives}

It has been shown that it is feasible and not cumbersome to perform noninvasive physiological measurements to evaluate the success or failure of transition and resuscitation if needed. However, more data is needed to develop a full understanding of the physiological mechanisms involved in adaptation to extrauterine life. This will help us to identify normal or delayed transition. It is of vital importance to improve our resuscitation strategies as the patients that need intervention will keep presenting at lower gestational ages with more complicated (pulmonary and hemodynamic) problems.

Currently, it is assumed that proper tidal volumes are in the range of $4-8 \mathrm{ml} / \mathrm{kg}$. However, a larger range in tidal volumes was measured in mask-ventilated healthy term and preterm infants $[49,117]$. Therefore, the safe range of adequate tidal volumes still needs to be determined. The use of a respiratory function monitor could improve our care during the neonatal transition by informing on spontaneous breathing, the amount of tidal volumes of inspired volumes and mask leak [16]. Furthermore, the use of a monitor guiding the resuscitation could also improve the outcome of infants needing resuscitation due to reducing lung injury and as a consequence reducing chronic lung disease and bronchopulmonary dysplasia.

Imaging techniques such as MRI could prove promising in improving our understanding of the mechanism of labor and its implications for the physiological chang- es taking place during birth [118]. Gas exchange measurements during transition, using capnography, could assist in defining adequate tidal volumes [96-98] and the total amount of proper gas exchange. However, this technique can be influenced by other variables such as mask leak and the dead space of the mask and sensor. Therefore, the value of capnography still needs to be determined. Capnography can immediately provide data on the effectivity of gas exchange, but does not provide information on the total amount of FRC. Measurement of the changes in FRC will be helpful in improving our ventilation strategies. This will however be challenging. FRC could be determined using noninvasive techniques such as respiratory inductance plethysmography, which could prove helpful in providing information on relative FRC changes and the work of breathing $[119,120]$. However, FRC measurements gathered with respiratory inductance plethysmography should be collected simultaneously with leak-free volume measurements in order to calculate the absolute changes in FRC. Furthermore, this will provide insight into the effectivity of mask ventilation and the effect of changing interventions. BP and PI measurements could help us to evaluate the hemodynamic transition. However, more data is needed to define reference values and temporal changes after birth. Both parameters are advisory on the physiological changes during transition in terms of circulation and perfusion and could be used to intervene if the transition is not taking place as it should. Echocardiography and NIRS have been shown to be valuable research tools for investigating transition. In particular, NIRS is useful to monitor the effect of transition on the most important organ of the human body (the brain) and may help to predict prognosis of the neurological outcome. In conclusion, these noninvasive physiological measurements will help us to translate concepts derived from current experimental studies to human infants and increase our knowledge of human physiology.

\section{References}

1 Karlberg P, Cherry RB, Escardo FE, Koch G: Respiratory studies in newborn infants. II. Pulmonary ventilation and mechanics of breathing in first minutes of life, including onset of respiration. Acta Paediatr Scand 1962;51:121-136.

2 te Pas AB, Davis PG, Hooper SB, Morley CJ: From liquid to air: breathing after birth. J Pediatr 2008;152:607-611.

Physiological Measurements during Neonatal Transition
Neonatology 2014;105:230-242 DOI: $10.1159 / 000356704$
5 Warnekros K: Schwangerschaft und Geburt im Rontgenbilde. Wiesbaden, Bergmann, 1917, pp 719-741. culation in the fetus and during the transitional period to air breathing. Eur J Obstet Gynecol Reprod Biol 1999;84:127-132.

4 Hooper SB, Kitchen MJ, Siew ML, Lewis RA, Fouras A, te Pas AB, Siu KK, Yagi N, Uesugi $\mathrm{K}$, Wallace MJ: Imaging lung aeration and lung liquid clearance at birth using phase contrast X-ray imaging. Clin Exp Pharmacol Physiol 2009;36:117-125.
6 Hooper SB, Harding R: Fetal lung liquid: a major determinant of the growth and functional development of the fetal lung. Clin Exp Pharmacol Physiol 1995;22:235-247. 
7 Vyas H, Field D, Milner AD, Hopkin IE: Determinants of the first inspiratory volume and functional residual capacity at birth. Pediatr Pulmonol 1986;2:189-193.

8 Dawes GS: Oxygen supply and consumption in late fetal life and the onset of breathing at birth; in Fenn WO, Rahn H (eds): Handbook of Physiology. Section 2. Respiration. Washington, American Physiological Society, 1965, pp 1313-1328.

-9 Harned HS Jr, Wolkoff AS, Pickrell J, MacKinney LG: Hemodynamic observations during birth of the lamb. Studies of the unanesthetized full-term animal. Am J Dis Child 1961;102:180-189.

-10 Davey MG, Moss TJ, McCrabb GJ, Harding R: Prematurity alters hypoxic and hypercapnic ventilatory responses in developing lambs. Respir Physiol 1996;105:57-67.

-11 Rigatto H, De LT, V, Gates DB: Effects of $\mathrm{O}_{2}$ on the ventilatory response to $\mathrm{CO}_{2}$ in preterm infants. J Appl Physiol 1975;39:896-899.

-12 O’Donnell CP, Kamlin CO, Davis PG, Morley CJ: Crying and breathing by extremely preterm infants immediately after birth. J Pediatr 2010;156:846-847.

13 Schilleman K, Siew ML, Lopriore E, Morley $\mathrm{CJ}$, Walther FJ, te Pas AB: Auditing resuscitation of preterm infants at birth by recording video and physiological parameters. Resuscitation 2012;83:1135-1139.

- 14 Bookatz GB, Mayer CA, Wilson CG, Vento M, Gelfand SL, Haxhiu MA, Martin RJ: Effect of supplemental oxygen on reinitiation of breathing after neonatal resuscitation in rat pups. Pediatr Res 2007;61:698-702.

-15 Saugstad OD, Rootwelt T, Aalen O: Resuscitation of asphyxiated newborn infants with room air or oxygen: an international controlled trial: the Resair 2 study. Pediatrics 1998; 102:e1.

- 16 Schilleman K, van der Pot CJ, Hooper SB, Lopriore E, Walther FJ, te Pas AB: Evaluating manual inflations and breathing during mask ventilation in preterm infants at birth. J Pediatr 2012;162:457-463.

17 Barker PM, Olver RE: Invited review: clearance of lung liquid during the perinatal period. J Appl Physiol 2002;93:1542-1548.

$\checkmark 18$ Siew ML, Wallace MJ, Kitchen MJ, Lewis RA, Fouras A, te Pas AB, Yagi N, Uesugi K, Siu $\mathrm{KK}$, Hooper SB: Inspiration regulates the rate and temporal pattern of lung liquid clearance and lung aeration at birth. J Appl Physiol 2009;106:1888-1895.

-19 Escobar J, Gormaz M, Arduini A, Gosens K, Martinez A, Perales A, Escrig R, Tormos E, Rosello M, Orellana C, Vento M: Expression of aquaporins early in human pregnancy. Early Hum Dev 2012;88:589-594.

20 Modi N: Clinical implications of postnatal alterations in body water distribution. Semin Neonatol 2003;8:301-306.

21 Zelenina M, Zelenin S, Aperia A: Water channels (aquaporins) and their role for postnatal adaptation. Pediatr Res 2005;57:47R-53R.
2 Riley CA, Boozer K, King TL: Antenatal corticosteroids at the beginning of the 21st century. J Midwifery Womens Health 2011;56: 591-597.

23 Borell U, Fernstrom I: The shape of the foetal chest during its passage through the birth canal. A radiographic study. Acta Obstet Gynecol Scand 1962;41:213-222.

24 Karlberg P: The first breaths of life; in Gluck L (ed): Modern Perinatal Medicine, year book ed. Chicago, Medical Publishers, 1974, pp 391-408.

25 Saunders RA, Milner AD: Pulmonary pressure/volume relationships during the last phase of delivery and the first postnatal breaths in human subjects. J Pediatr 1978;93: 667-673.

26 Stoeckel W: Lehrbuch der Geburtshilfe, ed 4. Jena, Gustav Fisher, 1920, p 226.

27 Bland RD: Loss of liquid from the lung lumen in labor: more than a simple 'squeeze'. Am J Physiol Lung Cell Mol Physiol 2001; 280:L602-L605.

28 Martius H, Bickenbach W: Leherbuch der Geburtshilfe, ed 3. Stuttgart, Thieme, 1956, p 79.

$\checkmark 29$ Lines A, Hooper SB, Harding R: Lung liquid production rates and volumes do not decrease before labor in healthy fetal sheep. J Appl Physiol 1997;82:927-932.

30 Avery ME, Frank NR, Gribetz I: The inflationary force produced by pulmonary vascular distention in excised lungs; the possible relation of this force to that needed to inflate the lungs at birth. J Clin Invest 1959;38:456462.

31 Jaykka S: Capillary erection and lung expansion; an experimental study of the effect of liquid pressure applied to the capillary network of excised fetal lungs. Acta Paediatr Suppl 1957;46:1-91.

32 von Basch SSK: Klinische und Experimentelle Studien. Berlin, Hirschwald, 1891, p 69.

33 Lauer RM, Evans JA, Aoki H, Kittle CF: Factors controlling pulmonary vascular resistance in fetal lambs. J Pediatr 1965;67:568-577.

- 34 Teitel DF, Iwamoto HS, Rudolph AM: Changes in the pulmonary circulation during birthrelated events. Pediatr Res 1990;27:372-378.

35 Olshausen R: Beitrag zur Lehre vom Mechanismus der Geburt. Suttgart, Enke, 1901, p 65.

36 Karlberg P, Adams FH, Geubelle F, Wallgren G: Alteration of the infant's thorax during vaginal delivery. Acta Obstet Gynecol Scand 1962;41:223-229.

37 Gruenwald P: Surface tension as a factor in the resistance of neonatal lungs to aeration. Am J Obstet Gynecol 1947;53:996-1007.

38 Bland RD: Dynamics of pulmonary water before and after birth. Acta Paediatr Scand Suppl 1983;305:12-20.

39 Miserocchi G, Poskurica BH, Del FM: Pulmonary interstitial pressure in anesthetized paralyzed newborn rabbits. J Appl Physiol 1994; 77:2260-2268.
40 Siew ML, te Pas AB, Wallace MJ, Kitchen MJ, Lewis RA, Fouras A, Morley CJ, Davis PG, Yagi N, Uesugi K, Hooper SB: Positive endexpiratory pressure enhances development of a functional residual capacity in preterm rabbits ventilated from birth. J Appl Physiol 2009; 106:1487-1493.

-41 te Pas AB, Wong C, Kamlin COF, Dawson JA, Morley CJ, Davis PG: Breathing patterns in preterm and term infants immediately after birth. Pediatr Res 2009;65:352-356.

42 Lind J, Peltonen T, Tornwall L, Wegelius C: Roentgenological lung findings in the newborn infant's 1st breath. Z Kinderheilkd 1963; 87:568-578.

43 Hooper SB, Kitchen MJ, Wallace MJ, Yagi N Uesugi K, Morgan MJ, Hall C, Siu KK, Williams IM, Siew M, Irvine SC, Pavlov K, Lewis RA: Imaging lung aeration and lung liquid clearance at birth. FASEB J 2007;21:33293337.

44 Miserocchi G, Agostoni E: Pleural liquid and surface pressures at various lung volumes. Respir Physiol 1980;39:315-326.

45 Thibeault DW, Wong MM, Auld PA: Thoracic gas volume changes in premature infants. Pediatrics 1967;40:403-411.

46 Bosma JF, Lind J: Roentgenologic observations of motions of the upper airway associated with establishment of respiration in the newborn infant. Acta Paediatr Suppl 1960;49: 18-55.

47 Karlberg P, Koch G: Respiratory studies in newborn infants. III. Development of mechanics of breathing during the first week of life. A longitudinal study. Acta Paediatr Suppl 1962;135:121-129.

48 te Pas AB, Davis PG, Kamlin CO, Dawson J, O'Donnell CP, Morley CJ: Spontaneous breathing patterns of very preterm infants treated with continuous positive airway pressure at birth. Pediatr Res 2008;64:281-285.

49 Mortola JP, Fisher JT, Smith JB, Fox GS, Weeks S, Willis D: Onset of respiration in infants delivered by cesarean section. J Appl Physiol 1982;52:716-724.

50 Clements JA: Surface tension of lung extracts. Proc Soc Exp Biol Med 1957;95:170-172.

51 Siew ML, te Pas AB, Wallace MJ, Kitchen MJ, Islam MS, Lewis RA, Fouras A, Morley CJ, Davis PG, Yagi N, Uesugi K, Hooper SB: Surfactant increases the uniformity of lung aeration at birth in ventilated preterm rabbits. $\mathrm{Pe}$ diatr Res 2011;70:50-55.

52 Winberg P, Jansson M, Marions L, Lundell BP: Left ventricular output during postnatal circulatory adaptation in healthy infants born at full term. Arch Dis Child 1989;64:13741378.

53 Kondo M, Itoh S, Kunikata T, Kusaka T, Ozaki T, Isobe K, Onishi S: Time of closure of ductus venosus in term and preterm neonates. Arch Dis Child Fetal Neonatal Ed 2001; 85:F57-F59. 
-54 Crossley KJ, Allison BJ, Polglase GR, Morley CJ, Davis PG, Hooper SB: Dynamic changes in the direction of blood flow through the ductus arteriosus at birth. J Physiol 2009;587: 4695-4704.

55 Rudolph AM: Hepatic and ductus venosus blood flows during fetal life. Hepatology 1983; 3:254-258.

-56 Kiserud T, Rasmussen S, Skulstad S: Blood flow and the degree of shunting through the ductus venosus in the human fetus. Am J Obstet Gynecol 2000;182:147-153.

57 Kiserud T, Eik-Nes SH, Blaas HG, Hellevik LR: Foramen ovale: an ultrasonographic study of its relation to the inferior vena cava, ductus venosus and hepatic veins. Ultrasound Obstet Gynecol 1992;2:389-396.

58 Rudolph AM: The changes in the circulation after birth. Their importance in congenital heart disease. Circulation 1970;41:343-359.

59 Heymann MA: Regulation of the pulmonary circulation in the perinatal period and in children. Intensive Care Med 1989;15:S9-S12.

-60 Lind J, Wegelius C: Human fetal circulation: changes in the cardiovascular system at birth and disturbances in the post-natal closure of the foramen ovale and ductus arteriosus. Cold Spring Harb Symp Quant Biol 1954;19:109125.

61 Bhatt S, Alison B, Wallace EM, Crossley KJ, Gill AW, Kluckow M, te Pas AB, Morley CJ, Polglase GR, Hooper SB: Delaying cord clamping until ventilation onset improves cardiovascular function at birth in preterm lambs. J Physiol 2013;591:2113-2126.

62 Rabe H, Diaz-Rossello JL, Duley L, Dowswell $\mathrm{T}$ : Effect of timing of umbilical cord clamping and other strategies to influence placental transfusion at preterm birth on maternal and infant outcomes. Cochrane Database Syst Rev 2012;8:CD003248.

63 Aladangady N, McHugh S, Aitchison TC, Wardrop CA, Holland BM: Infants' blood volume in a controlled trial of placental transfusion at preterm delivery. Pediatrics 2006; 117:93-98.

64 Linderkamp O: Placental transfusion: determinants and effects. Clin Perinatol 1982;9: 559-592.

- 65 Stembera ZK, Hodr J, Janda J: Umbilical blood flow in healthy newborn infants during the first minutes after birth. Am J Obstet Gynecol 1965;91:568-574.

66 Yao AC, Hirvensalo M, Lind J: Placental transfusion rate and uterine contraction. Lancet $1968 ; 1: 380-383$.

67 Richmond S, Wyllie J: European Resuscitation Council guidelines for resuscitation 2010. Section 7. Resuscitation of babies at birth. Resuscitation 2010;81:1389-1399.

-68 Dawson JA, Kamlin CO, Wong C, te Pas AB, Vento M, Cole TJ, Donath SM, Hooper SB, Davis PG, Morley CJ: Changes in heart rate in the first minutes after birth. Arch Dis Child Fetal Neonatal Ed 2010;95:F177-F181.
69 Klingenberg C, Sobotka KS, Ong T, Allison BJ, Schmölzer GM, Moss TJ, Polglase GR, Dawson JA, Davis PG, Hooper SB: Effect of sustained inflation duration; resuscitation of near-term asphyxiated lambs. Arch Dis Child Fetal Neonatal Ed 2013;98: F222-F227.

70 Carbonne B, Langer B, Goffinet F, Audibert F, Tardif D, Le GF, Laville M, Maillard F: Multicenter study on the clinical value of fetal pulse oximetry. II. Compared predictive values of pulse oximetry and fetal blood analysis. The French Study Group on Fetal Pulse Oximetry. Am J Obstet Gynecol 1997;177:593-598.

71 Kubli FW, Hon EH, Khazin AF, Takemura H: Observations on heart rate and $\mathrm{pH}$ in the human fetus during labor. Am J Obstet Gynecol 1969;104:1190-1206.

72 Kuhnert M, Seelbach-Goebel B, Butterwegge M: Predictive agreement between the fetal arterial oxygen saturation and fetal scalp $\mathrm{pH}$ : results of the German multicenter study. Am J Obstet Gynecol 1998;178:330-335.

-73 Seelbach-Gobel B, Heupel M, Kuhnert M, Butterwegge M: The prediction of fetal acidosis by means of intrapartum fetal pulse oximetry. Am J Obstet Gynecol 1999;180:73-81.

74 Palme-Kilander C, Tunell R, Chiwei Y: Pulmonary gas exchange immediately after birth in spontaneously breathing infants. Arch Dis Child 1993;68:6-10.

75 O’Donnell CP, Kamlin CO, Davis PG, Carlin JB, Morley CJ: Clinical assessment of infant colour at delivery. Arch Dis Child Fetal Neonatal Ed 2007;92:F465-F467.

-76 Dawson JA, Davis PG, O’Donnell CP, Kamlin $\mathrm{CO}$, Morley CJ: Pulse oximetry for monitoring infants in the delivery room: a review. Arch Dis Child Fetal Neonatal Ed 2007;92:F4-F7.

77 Dawson JA, Kamlin CO, Vento M, Wong C, Cole TJ, Donath SM, Davis PG, Morley CJ: Defining the reference range for oxygen saturation for infants after birth. Pediatrics 2010; 125:e1340-e1347.

78 Nuntnarumit P, Rojnueangnit K, Tangnoo A: Oxygen saturation trends in preterm infants during the first $15 \mathrm{~min}$ after birth. J Perinatol 2010;30:399-402.

79 Rabi Y, Yee W, Chen SY, Singhal N: Oxygen saturation trends immediately after birth. J Pediatr 2006;148:590-594.

80 Sharma A, Ford S, Calvert J: Adaptation for life: a review of neonatal physiology. Anaesthesia and intensive care medicine 2010;12: 85-90.

-81 Van Hare GF, Hawkins JA, Schmidt KG, Rudolph AM: The effects of increasing mean arterial pressure on left ventricular output in newborn lambs. Circ Res 1990;67:78-83.

82 Agata Y, Hiraishi S, Oguchi K, Misawa H, Horiguchi Y, Fujino N, Yashiro K, Shimada $\mathrm{N}$ : Changes in left ventricular output from fetal to early neonatal life. J Pediatr 1991;119: 441-445.

83 Popat H, Kluckow M: Noninvasive assessment of the early transitional circulation in healthy term infants. Neonatology 2012;101: 166-171.
84 Walther FJ, Benders MJ, Leighton JO: Early changes in the neonatal circulatory transition. J Pediatr 1993;123:625-632.

85 Noori S, Wlodaver A, Gottipati V, McCoy M, Schultz D, Escobedo M: Transitional changes in cardiac and cerebral hemodynamics in term neonates at birth. J Pediatr 2012;160: 943-948.

86 Kluckow M, Evans N: Relationship between blood pressure and cardiac output in preterm infants requiring mechanical ventilation. J Pediatr 1996;129:506-512.

87 Woodbury RA, Robinow M, Hamilton WF: Blood pressure studies on infants. 1938;122: 472-479.

$\checkmark 88$ Salihoglu O, Can E, Beskardes A, Koc BS, Tan I, Can G, Hatipoglu S: Delivery room blood pressure percentiles of healthy, singleton, liveborn neonates. Pediatr Int 2012;54:182189.

89 Ashworth AM, Neligan GA: Changes in the systolic blood pressure of normal babies during the first twenty-four hours of life. Lancet 1959;1:804-807.

-90 Urlesberger B, Grossauer K, Pocivalnik M, Avian A, Muller W, Pichler G: Regional oxygen saturation of the brain and peripheral tissue during birth transition of term infants. J Pediatr 2010;157:740-744.

91 Palme-Kilander C, Tunell R: Equipment for recording pulmonary gas exchange immediately after birth during spontaneous breathing and assisted ventilation. Med Biol Eng Comput 1993;31:67-71.

92 Tunell R, Copher D, Persson B: Pulmonary gas exchange and blood gases in the immediate neonatal period. Acta Obstet Gynecol Scand 1969;48:90.

93 Palme-Kilander C, Tunell R: Pulmonary gas exchange during facemask ventilation immediately after birth. Arch Dis Child 1993;68: $11-16$.

94 Rurak DW, Gruber NC: Increased oxygen consumption associated with breathing activity in fetal lambs. J Appl Physiol 1983;54:701707.

95 Kong JY, Rich W, Finer NN, Leone TA: Quantitative end-tidal carbon dioxide monitoring in the delivery room: a randomized controlled trial. J Pediatr 2013;163:104-108.

-96 Nangia S, Saili A, Dutta AK: End tidal carbon dioxide monitoring - its reliability in neonates. Indian J Pediatr 1997;64:389-394.

97 Rozycki HJ, Sysyn GD, Marshall MK, Malloy $\mathrm{R}$, Wiswell TE: Mainstream end-tidal carbon dioxide monitoring in the neonatal intensive care unit. Pediatrics 1998;101:648-653.

$98 \mathrm{Wu} \mathrm{CH}$, Chou HC, Hsieh WS, Chen WK, Huang PY, Tsao PN: Good estimation of arterial carbon dioxide by end-tidal carbon dioxide monitoring in the neonatal intensive care unit. Pediatr Pulmonol 2003;35:292-295.

$\checkmark 99$ Hooper SB, Fouras A, Siew ML, Wallace MJ, Kitchen MJ, te Pas AB, Klingenberg C, Lewis RA, Davis PG, Morley CJ, Schmölzer GM: Expired $\mathrm{CO}_{2}$ levels indicate degree of lung aeration at birth. Plos One 2013;8:e70895.
Physiological Measurements during Neonatal Transition
Neonatology 2014;105:230-242

DOI: $10.1159 / 000356704$ 
100 Milner AD, Saunders RA: Pressure and volume changes during the first breath of human neonates. Arch Dis Child 1977;52:918924.

101 De FC, Latini G, Vacca P, Kopotic RJ: The pulse oximeter perfusion index as a predictor for high illness severity in neonates. Eur J Pediatr 2002;161:561-562.

-102 De FC, del VA, Criscuolo M, Lozupone A, Parrini S, Latini G: Early postnatal changes in the perfusion index in term newborns with subclinical chorioamnionitis. Arch Dis Child Fetal Neonatal Ed 2005;90:F411F414.

103 Urlesberger B, Kratky E, Rehak T, Pocivalnik M, Avian A, Czihak J, Muller W, Pichler G: Regional oxygen saturation of the brain during birth transition of term infants: comparison between elective cesarean and vaginal deliveries. J Pediatr 2011;159:404-408.

104 Brugada M, Schilleman K, Witlox RS, Walther FJ, Vento M, te Pas AB: Variability in the assessment of 'adequate' chest excursion during simulated neonatal resuscitation. Neonatology 2011;100:99-104.

105 International Liaison Committee on Resuscitation: The International Liaison Committee on Resuscitation (ILCOR) consensus on science with treatment recommendations for pediatric and neonatal patients: neonatal resuscitation. Pediatrics 2006;117:e978e988.
06 Kattwinkel J, Perlman JM, Aziz K, Colby C, Fairchild K, Gallagher J, Hazinski MF, Halamek LP, Kumar P, Little G, McGowan JE, Nightengale B, Ramirez MM, Ringer S, Simon WM, Weiner GM, Wyckoff M, Zaichkin J: Neonatal resuscitation: 2010 American Heart Association guidelines for cardiopulmonary resuscitation and emergency cardiovascular care. Pediatrics 2010; 126:e1400-e1413.

107 Poulton DA, Schmölzer GM, Morley CJ, Davis PG: Assessment of chest rise during mask ventilation of preterm infants in the delivery room. Resuscitation 2011;82:175-179.

108 Schmölzer GM, Kamlin OC, O’Donnell CP, Dawson JA, Morley CJ, Davis PG: Assessment of tidal volume and gas leak during mask ventilation of preterm infants in the delivery room. Arch Dis Child Fetal Neonatal Ed 2010;95:F393-F397.

109 Schmölzer GM, Kamlin CO, Dawson JA, Morley CJ, Davis PG: Tidal volume delivery during surfactant administration in the delivery room. Intensive Care Med 2011;37: 1833-1839.

110 Schmölzer GM, Morley CJ, Wong C, Dawson JA, Kamlin CO, Donath SM, Hooper SB, Davis PG: Respiratory function monitor guidance of mask ventilation in the delivery room: a feasibility study. J Pediatr 2012;160: 377-381.

111 Milner AD, Vyas H, Hopkin IE: Efficacy of facemask resuscitation at birth. Br Med J (Clin Res Ed) 1984;289:1563-1565.

112 Hull D: Lung expansion and ventilation during resuscitation of asphyxiated newborn infants. J Pediatr 1969;75:47-58.
13 Head H: On the regulation of respiration. Part I. Experimental. J Physiol 1889;10:1152.

114 Cross KW: Head's paradoxical reflex. Brain 1961;84:529-534.

115 Boon AW, Milner AD, Hopkin IE: Physiological responses of the newborn infant to resuscitation. Arch Dis Child 1979;54:492498.

116 Hannam S, Ingram DM, Rabe-Hesketh S, Milner AD: Characterisation of the HeringBreuer deflation reflex in the human neonate. Respir Physiol 2001;124:51-64.

117 Murthy V, Dattani N, Peacock JL, Fox GF, Campbell ME, Milner AD, Greenough A: The first five inflations during resuscitation of prematurely born infants. Arch Dis Child Fetal Neonatal Ed 2012;97:F249-F253.

118 Bamberg C, Rademacher G, Guttler F, Teichgraber U, Cremer M, Buhrer C, Spies C, Hinkson L, Henrich W, Kalache KD, Dudenhausen JW: Human birth observed in real-time open magnetic resonance imaging. Am J Obstet Gynecol 2012;206:505-506.

119 Courtney SE, Pyon KH, Saslow JG, Arnold GK, Pandit PB, Habib RH: Lung recruitment and breathing pattern during variable versus continuous flow nasal continuous positive airway pressure in premature infants: an evaluation of three devices. Pediatrics 2001; 107:304-308.

120 Stick SM, Ellis E, LeSouef PN, Sly PD: Validation of respiratory inductance plethysmography ('Respitrace') for the measurement of tidal breathing parameters in newborns. Pediatr Pulmonol 1992;14:187-191. 